\title{
CONTESTED PLACES: THE SIGNIFICANCE OF THE MOTUNUI-WAITARA CLAIM TO THE WAITANGI TRIBUNAL
}

\author{
Paul James and Eric Pawson
}

\section{Introduction}

The Waitangi Tribunal is the statutory body charged in New Zealand with investigation of Maori grievances against the Crown that stem from alleged breaches of the Treaty of Waitangi. ${ }^{1}$ In a series of reports the Tribunal has provided a means of demonstrating that places and landscapes do not have single, essential identities. The Motunui-Waitara claim, of the Atiawa people of Taranaki, was the first case dealt with by the Tribunal that received nationwide focus. The Tribunal reported on the claim in 1983. It drew the attention of a broader public to differences between Maori and Pakeha (white settler) concepts of the environment and environmental behaviour, and the ways in which these are expressed in different places. The purpose of this article is therefore to sketch and evaluate the geographies of this particular claim, in order to demonstrate and account for cultural differences in environmental behaviours in a specific place.

Central to the account is the concept of place: how people make places and the significance that different peoples attach to different elements of place. Places are therefore taken to be socially constructed and to bear the marks of contestation. ${ }^{2}$ The places of the New Zealand landscape, like any other, are not neutral, but reflect power relations and dominant ways of seeing the world. ${ }^{3}$ Those dominant ways of seeing are sometimes claimed to have 'erased' alternatives, whereas they have rather rendered them hidden through a refusal to read 'other' narratives (in this case, the primarily oral geographies of the Maori). In reality, place is 'a hotly contested site', those contests being of physical possession, naming, mapping and 'of tribal, racial and personal memory'. ${ }^{4}$ Differences between Maori and Pakeha attitudes to the environment are located in differences of history and culture, and it is windows into these that Tribunal reports provide. The broader context of the MotunuiWaitara claim and the wider impact of the 'Tribunal's report since its publication in 1983 also serve to illustrate the ways in which what happens in particular places is both affected by processes originating at broader spatial scales and can in turn have wider impacts, affecting places elsewhere.

\section{Sense/s of Place}

Domestic airline flights between the cities of Auckland and Christchurch pass directly over Taranaki, using that region's most prominent icon, the volcanic peak of Mt. Taranaki, as a navigational marker (Fig 1). The tip of the peak lies invisible to passengers, being

Paul James is a Senior Policy Analyst with The Office of Treaty Settlements, PO Box 919, Wellington.

Eric Pawson is Associate Professor in the Department of Geography at the University of Canterbury, Private Bag 4800, Christchurch.
Stokes 1992.
Short 1991.
McDowell 1994.
Pitts 1992: 87. 


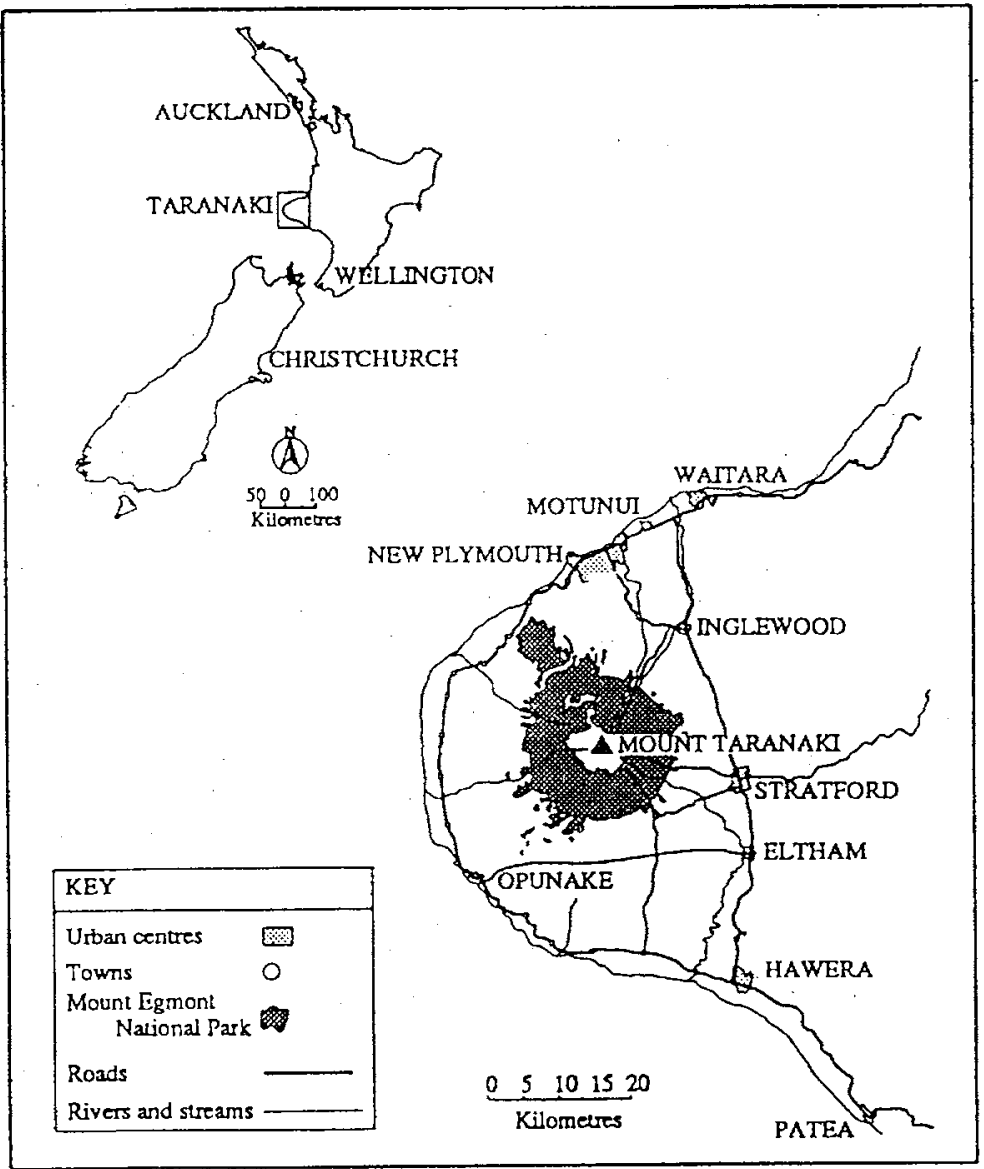

\section{FIgure 1. Location Map}

directly beneath the plane, but the slopes of the cone can be clearly seen. They are thrown into prominence by an abrupt circular boundary carved between the forest that still stands on the lower fringes of the mountain and the complex patchwork of fields and roads that makes up the landscape beyond.

The circular boundary is that of the Egmont national park, named for a European sailor. The mountain at its centre was long known on Pakeha maps as Mount Egmont, but in the mid 1980s, the New Zealand Geographic Board decreed that it could also officially resume its original Maori name, Taranaki. The starkness of the park boundary from above symbolises the imposed geometry and the ordered regularity of the farming landscape that has so often characterised the appropriation and reordering of indigenous territories by Europeans. For centuries Taranaki was home to a substantial Maori population which was dispossessed of its lands in the New Zealand wars of the 1860s. One iwi (tribe) which 


\section{THE MONTUNUI-WAITARA CLAIM TO THE WATTANGI TRIBUNAL}

fought against the Crown was Te Atiawa, thereafter being left with little but the food bearing coastal reefs along the margins of its former territory.

These reefs are clearly visible from the air, fringing the coastline of north Taranaki, defying the regularity and order of the farms and roads. 'Collectively they constitute one of the most extensive traditional fishing reefs of the Maori people'. 5 They have long provided Te Atiawa with both sustenance and (as a means of feeding guests) honour and prestige (mana). Pakeha activities in the appropriated landscape however have led to increasing pollution and health problems for reef users. It was a large scale industrial proposal which would have generated still further pollution that prompted the iwi to take a grievance to the Waitangi Tribunal.

\section{A Pakeha Geography of Taranaki (Fig 2)}

The Pakeha appropriation of Taranaki was part of the British colonisation of Maori Aotearoa, which itself can only be understood as a component of the global expansion of nineteenth century capitalism. But although the town of New Plymouth was established at the relatively early date of 1841 (within a year of the signing of the Treaty of Waitangi between Maori chiefs and the British Crown), Pakeha settlement of the region was slow. Of the 101,214 European immigrants arriving in New Zealand as a whole to 1882, only 2,223 went to Taranaki, compared with Canterbury in the South Island which received 57,695 immigrants in the same period. 6

These figures reflect the inherent difficulties for Pakeha in settling a place that was for them insecure, where access to land was actively contested by indigenous owners and where the land itself was heavily forested. In these respects the situation in Taranaki was a microcosm of that for Pakeha in the North Island as a whole. The wars of the 1860s were initiated by the Crown as part of a strategy to increase its tenuous authority in the North Island, using as a pretext an incident concerning disputed sale of Te Atiawa land in the Waitara district. ${ }^{7}$ The conflict in Taranaki prompted the Crown to confiscate substantial territories in 1863. Although active and peaceful resistance from Maori continued south of New Plymouth, land confiscations (raupatu) drove the Atiawa from their land in north Taranaki into the inland hill country, from which they did not emerge until 1872, and then on government terms. As 'rebellious people', they did not regain legal (ie Crown recognised) ownership to their lands (Fig 3).

Subsequent Pakeha development of the land depended on clearance of the forest, ${ }^{8}$ an enterprise celebrated in progressive terms. 'The axe, the slasher, and fire, in the hands of the settler, worked wonders. Comparatively few years were sufficient to demolish the growth of centuries:. 9 The trees were replaced by grass, setting the stage for farm based production. Initially this was limited by a lack of the infrastructure necessary for Taranaki's participation in interregional and export trade. However a railway was completed between New Plymouth and Stratford in 1879 and was linked up with a line from Wellington in 1885. Contemporaneously New Plymouth became a key port in the coastal trade between Auckland and the southern provinces. ${ }^{10}$ With the advent of refrigeration in the $1880 \mathrm{~s}$,

\footnotetext{
5 Waitangi Tribunal 1983: 9.

6 Rawson 1967: 25.

7 Belich 1986; Sinclair 1991.

8 Arnold 1994.

9 Stratford Jubilee 1928: 7.

10 Pawson 1992a.
} 


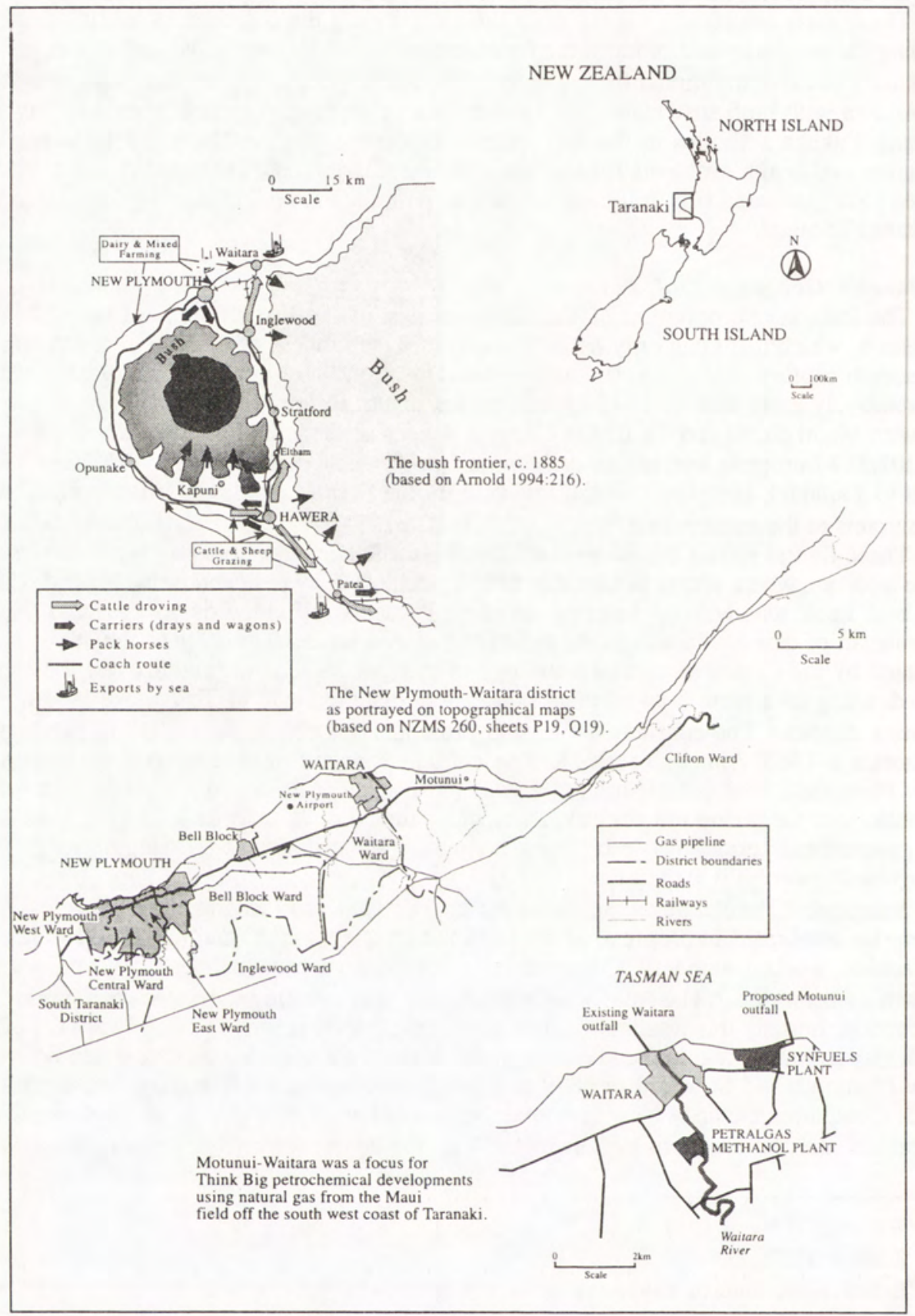

Figure 2. Pakeha Place in Taranaki 


\section{THE MONTUNUI-WAITARA CLAIM TO THE WAITANGI TRIBUNAL}

expansion of the export trade in dairy products and meat was possible, and with the construction of rural roads a network of local dairy factories developed. By the 1940s, there were about two hundred small cooperative dairy companies throughout Taranaki and two meatworks on the fringes of the cow country.

In recent decades Taranaki has achieved prominence in another sector of New Zealand's economy. In 1969 the Maui gasfield was found some 50 kilometres offshore, ten years after the discovery of the Kapuni onshore gas and condensate field. Together these constitute one of the larger natural gas fields in the world. The manner of their exploitation was dictated by a report from the Liquid Fuels Trust Board (LFTB), established by parliament in 1973 (in the wake of the international 'oil crisis') to recommend ways in which transport fuels could be produced in New Zealand using domestic resources. ${ }^{11}$ Following the second oil crisis at the end of the 1970s, the National Government established its 'Think Big' programme to promote rapid heavy industrialisation using domestic energy supplies, in order to maximise short term economic growth. ${ }^{12}$

Taranaki became one of the key foci of the Think Big programme. The LFTB recommended that 50-60 petajoules of Maui gas should be allocated each year for the manufacture of synthetic petrol and that chemical grade methanol for export should be made from the same source. These recommendations took form as the Petralgas Chemicals New Zealand (Petralgas) and New Zealand Synthetic Fuels Corporation (Synfuels) plants in north Taranaki. In addition an ammonia/urea works was established at Kapuni. These plants represented state of the art technology, but it was the technocratic approach to their environmental implications which was ultimately responsible for revealing the manner in which they symbolised a Pakeha and exclusionary narrative of the landscape (Fig 2).

\section{The Waitangi Tribunal and the Motunui-Waitara Claim}

Over the last century the imprint of both state policies and the broader processes of global capitalism have been apparent in the development of the Taranaki landscape. In the 1970 s, these wider links were fused in the state's response to the oil crises of that decade through its involvement with multinational capital in the Think Big projects. The Synfuels plant, for example, was a joint venture between the state and Mobil Oil, the latter providing 25 percent of the capital. At the same time however, events in a wider cultural global sphere also facilitated the hearing of the voices of those people previously excluded from the dominant discourse of place in north Taranaki. ${ }^{13}$ The 1960 s and 1970 s saw widespread decolonisation of the Third World, including those island states of the Pacific with which New Zealand has close links. Television enabled civil rights activism in the United States to be seen the world over; the United Nations took an increasing interest in indigenous peoples. There was thus an international context within which Maori activism in New Zealand developed. At the level of the state this activism was recognised when the Third Labour Government established the Waitangi Tribunal in 1975. 14

The Tribunal was seen by government as a minimalist means of defusing dissent that in the same year had grown to the point of producing a conspicuously large and assertive Land March through the North Island into the grounds of Parliament in Wellington. It was thought that such an agency might once again direct Maori disaffection out of the public

\footnotetext{
11 Maiden 1983: 33.

12 Peet 1981: 26.

13 James 1993.
}

14 Pawson and Cant 1992. 


\section{ABORIGINAL HISTORY 1995 19:2}

arena back into the courtroom, ${ }^{15}$ a venue within which Maori had themselves tried, for over a century with little success, to seek redress for loss of territory. ${ }^{16}$ The Tribunal was empowered to inquire into claims from any Maori or group of Maori that they had been prejudicially affected by actions of the Crown since the date of passage of the Act, which the claimants believed were inconsistent with the principles of the Treaty of Waitangi. Historical land claims could not therefore fall within the Tribunal's purview; neither could it enforce its findings, its role being solely that of making recommendations for action, if deemed necessary, to the government of the day.

The Tribunal made little impact for several years. It followed Pakeha protocols in its operation and was not seen by Maori as an appropriate forum for the investigation of grievances. However for the first time in 1981 a Maori became Chief Judge of the Maori Land Court and, by virtue of this position, chair of the Tribunal. The first case heard subsequently was the Motunui-Waitara claim, 'the turning point in the life of the Tribunal' ${ }^{17}$ For the first time it met on a marae (a meeting house, called in the case Manukorihi) belonging to the claimant tribe, adopted procedures more in keeping with the culture and experience of those claimants, and accorded their world view and environmental insights equal standing with those of Pakeha tradition.

The claim had been brought by Te Atiawa to protest the pollution of the north Taranaki reefs by existing and proposed future waste discharges from the town of Waitara (population 6012 in 1981) and the new Think Big projects. Until the completion of the Waitara marine outfall in 1978, industrial and domestic waste from that part of north Taranaki had been discharged directly into the Waitara river. This included semi raw sewage from the Waitara Borough's septic tanks and effluent from the Borthwicks (subsequently AFFCO) freezing works. It was not until 1956 that there was some preliminary treatment of the latter to remove most sediment fat and other solids. In 1967 polluted shellfish were implicated in an outbreak of typhoid in nine local Maori. In 1972, the Borough Council concluded that the pollution of the river could not continue and in 1973 a water right was granted by the Taranaki Regional Water Board for the discharge of waste through a marine outfall. Borthwicks paid for 72.8 percent of its capital cost.

The integrity of the Waitara outfall was questionable from the outset ${ }^{18}$ Due to problems experienced during the launch, two of the five diffuser ports were against the ocean floor and 70 percent of the effluent was discharging from one of the three remaining ports. There was no secondary or tertiary treatment of this effluent and the outfall was poorly located, being between two reefs and adjacent to the borough (see Figs 2 and 3). Freezing works waste was subsequently found on nearby beaches and reefs, ${ }^{19}$ and bacteriological tests undertaken by the Taranaki Catchment Commission (TCC) showed that the shoreline waters in the vicinity were not meeting quality requirements set in the water right.

Concerns stemming from the Waitara outfall's deficiencies were exacerbated with proposals to dispose of waste from the Think Big projects in similar ways. In 1980, Petralgas applied to the Planning Tribunal to discharge directly into the Waitara river from its methanol plant in the Waitara valley (see Figs 2 and 3). After a number of negative

15 Oliver 1991: 9-10.

16 Walker 1990.

17 Oliver 1991: 10.

18 James 1993.

19 Kirk 1984: 5. 


\section{THE MONTUNUI-WATTARA CLAIM TO THE WATTANGI TRIBUNAL}

submissions from agencies such as the TCC and the Ministry of Agriculture and Fisheries, it successfully changed its application to discharge through the existing Waitara outfall. No opportunity was given to local people to comment on the addition of industrial waste, which included heavy metals, to the Waitara outfall load. ${ }^{20}$ Synfuels then applied for, and in December 1981 was granted, consents by the Planning Tribunal for the construction of a stand alone marine outfall at Motunui.

The Motunui outfall met with objections from people mindful of the inadequacies of the existing Waitara outfall, and of the proliferation of outfalls along this stretch of coast (the New Plymouth outfall west of Waitara had just been installed). Te Atiawa and environmental groups took objections to the Regional Water Board at the various water rights hearings; made submissions to the Commissioner for the Environment's audit of the Synfuels and Petralgas environmental impact reports; made submissions to the Planning Tribunal hearings and then protested the Tribunal's Motunui decision in the Court of Appeal. All this being of no avail, Te Atiawa submitted to the Waitangi Tribunal that they were:

prejudicially affected by the policy or practice adopted by or on behalf of the Crown which results in failure to properly control discharge of sewage and industrial waste into the sea between New Plymouth and Waitara such policy or practice being inconsistent with the principles of the Treaty of Waitangi in that it has in particular adversely affected fishing grounds known as Tauanga, Te Puna, Titi Rangi and Orapa reefs belonging to Manukorihi, Otaraua and Ngati Rahiri hapu. 21

The claim was made more specific in the course of the hearing, in particular to include the Motunui outfall, the Tribunal being of a mind that the expression of grievances should not be constrained by 'undue legalism'? 22

\section{A Maori Geography of north Taranaki (Fig 3)}

The subsequent Tribunal hearing and its report acted as means by which Pakeha could begin to see the place of north Taranaki through different eyes: they exposed the Maori geography of the region to a much wider audience. One writer has referred to the process started by this and subsequent Tribunal reports as part of a 'radical reinterpretation' of New Zealand's history. ${ }^{23}$ For Pakeha in the early 1980s, the exposure of a hidden history of places such as north Taranaki was radical. It questioned the assumed universality of Pakeha landscape ideals. In this sense, the newfound accessibility of Maori place alongside that of the dominant tradition was a 'reinterpretation'; in another sense it was a retrieval for Pakeha of a geography that had always been there; the reading of a narrative that they did not know how to see.

The evidence heard by the Tribunal made it clear that Maori environmental relations contrast sharply with the basic duality of people 'apart from' nature that is central to Pakeha tradition. ${ }^{24}$ Rather Maori envisage themselves as 'part of' nature, personifying its different elements as an environmental family. ${ }^{25}$ Although people have a superordinate position in nature, there is a kinship between all things, with whakapapa (genealogy) used to establish

\footnotetext{
20 Waitangi Tribunal 1983: 30.

21 Waitangi Tribunal, 1983: 76.

22 Waitangi Tribunal, 1983: 8.

23 Sorrenson, 1989.

24 Durie 1987.

25 Yoon 1986.
} 


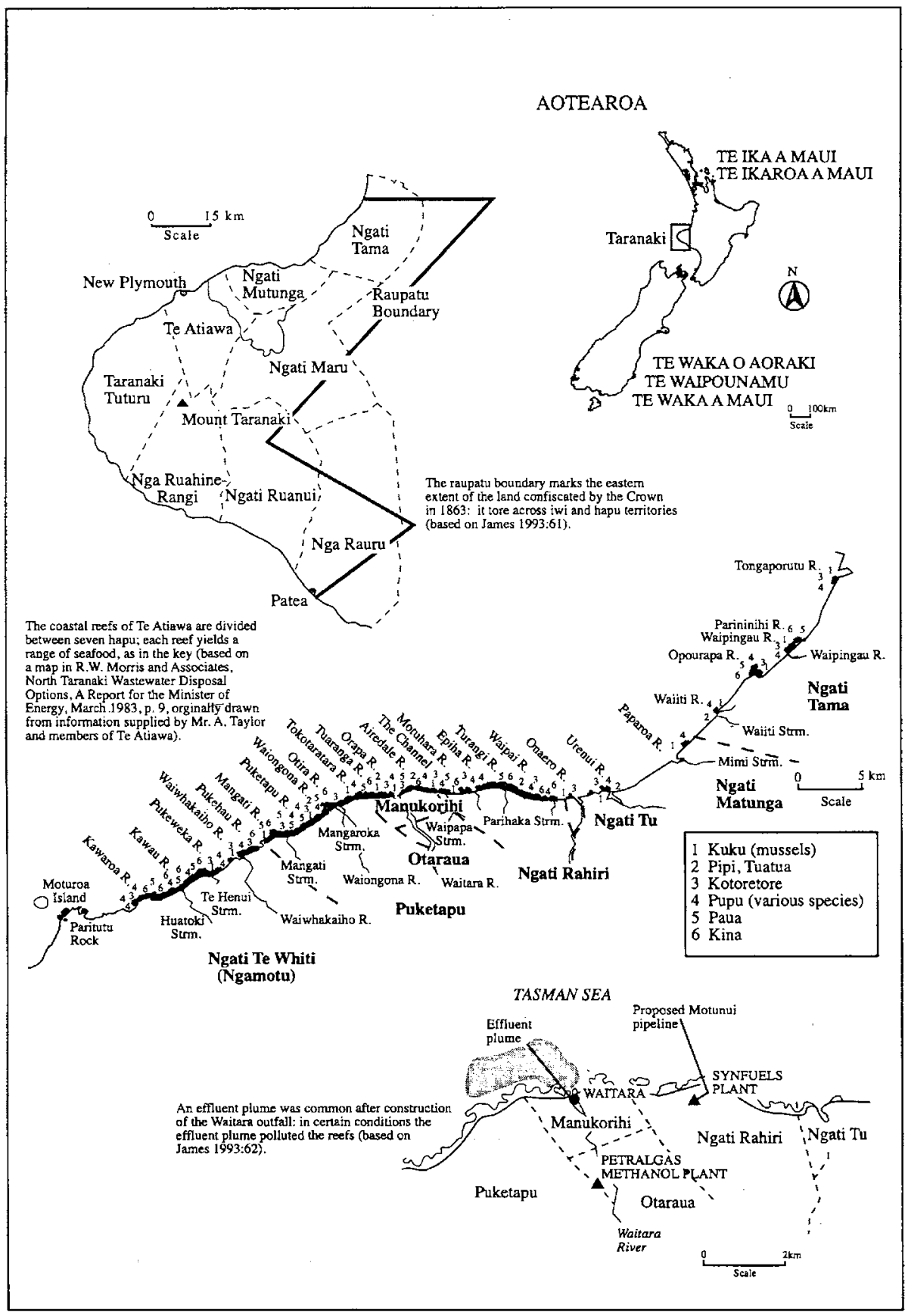

Figure 3. Te Atlawa Place in Taranakl 
the links between people and land. Land identifies the people and people identify with the land: out of this spiritual and historical association comes the status of Maori as tangata whenua - literally people who belong to the land. Maori are 'of' the land, as they have maintained a mutual covenant with Papa-tu-a-Nuku (the earth mother) since the beginning of history. ${ }^{26}$ [An alternative, not necessarily conflicting, interpretation is that this cultural bond was evolved through time in order to sustain resources for purposes of survival].

Following raupatu Te Atiawa became known as 'te iwi o te wahi kore' - the people with nothing. Confiscation tore apart their sense of place:

For Te Atiawa land [including the coastline] was everything. It was the foundation of life, the permanency and stability which provided the basis of economic and social survival. Every aspect of life for Te Atiawa involved land. It provided the history, the culture, the food of life and the politics. Te Atiawa was an integral part of the land, its environments and nature's endowments of the land. Every social activity was influenced by the land, the respect for land was paramount and in over a thousand years of occupation, Te Atiawa had nurtured the resources of the land and the sea:.27

With the loss of land Te Atiawa mana became focussed on their water resources. In evidence to the Tribunal, an elder asserted the importance of the Waitara river: 'my people personify the river, an entity aligned to our ancestor Maruwaranui, with the spirit or taniwha of the river. Those who cast pollution onto the spirit of the river are casting it onto the spirit of my people'. The coastal reefs, which Te Atiawa had stewarded for centuries, likewise assumed an even more important role. The Tribunal was told that '... maitaitai [seafood] is very valuable, more valuable than meat - without that our table is nothing'. ${ }^{28}$ Aila Taylor, the tribe's chief spokesperson, has summarised the importance of the reefs, demonstrating the social construction of the Atiawa environment:

Reef use exclusive to hapu

The reefs of the north Taranaki coast are divided up between seven hapu. It is not done to gather food from another hapu's reef. If a reef is spoiled by an outfall then that family group may be deprived altogether.

\section{Much of our seafood is eaten raw}

We gather a large number of different species from the reefs including $k u k u, k i n a$, paua, wheke, kotoretore, pipi and crabs. Much of this can be eaten raw. We have had people suggest that outfalls are no risk to health because everyone cooks their seafood.

Seafood is the 'crown' of our tables

The warmth of a welcome to guests is measured by the quality of the food provided, in particular the quantities and varieties of seafood. Our marae runs on voluntary effort, we have little money, we could not possibly afford to buy the things that we catch and gather.

Cleanliness on the reefs

We have an extensive set of customs which keep the reefs healthy by not polluting them in any way and by not overfishing. For example shellfish are not eaten on the

\footnotetext{
26 Henare 1988.

27 Love 1991: 11-12.

28 Waitangi Tribunal 1983: 12.
} 
reef, women do not gather while menstruating, people do not urinate whilst on the beach, a stretch of coastline is declared out of bounds for a period if someone is killed at sea until after the body is found (a rahui)..

What comes from the earth goes back to the earth

We believe that human waste should go back to the earth. We believe that anything to do with human waste should have nothing to do with food; clothes should be washed separately from tea towels; people should not sit on food tables; seafood should not be gathered from reefs polluted by an outfall. This belief is not just related to 'scientifically detectable' pollution; even if scientists 'proved' that an outfall was not polluting, we would be unhappy gathering seafoods from a reef near such an outfall' 29

The Tribunal hearing provided a forum in which Te Atiawa geography of north Taranaki was revealed, uncovering the Atiawa relationship to environment and resources. It demonstrated the critical differences between this geography and that of the Pakeha. Rather than water being a convenient carriageway for the passage of wastes, for example, it was shown that the traditional Maori view is that water is tapu (sacred), and once polluted by effluent it remains culturally polluted even if treated to standards set down by Pakeha science (Fig 4). And since each reef has significance to different hapu, it could not be argued that containment of pollution to certain parts of the coast would resolve the problem.

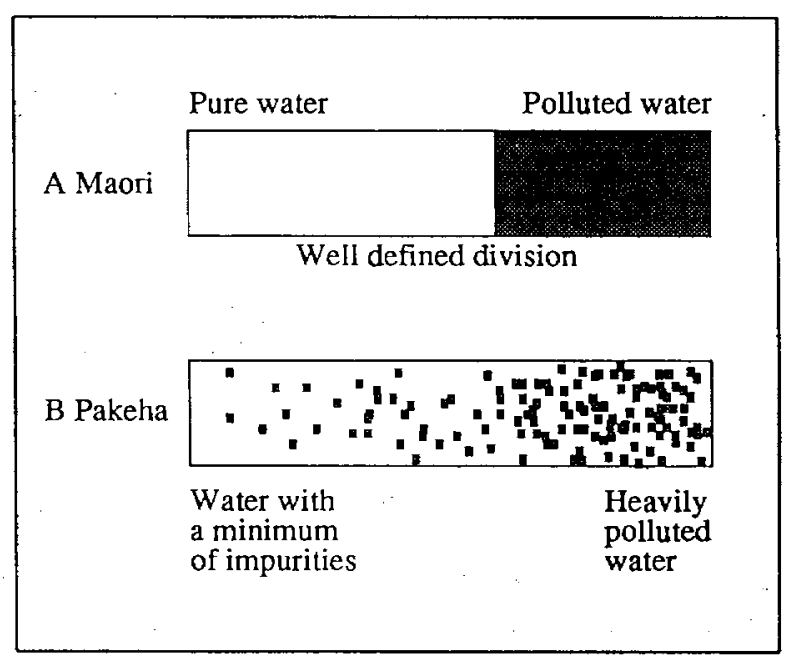

Flgure 4. Maori and Pakeha Representations of Water

29 Taylor 1986: 2; also Waitangi Tribunal 1983: 12-14. 


\section{THE MONTUNUI-WAITARA CLAIM TO THE WATTANGI TRIBUNAL}

The centrality of water in the claim, as opposed to its marginality in the industrialisation of the region, was clearly revealed as a product of the history of place, following the remaking of north Taranaki in the wake of land confiscation. And the legitimacy of the claim was supported by reference to the principles of the Treaty, in both its Maori and English texts. The first of these gives Maori '... the unqualified exercise of their chieftainship over their lands, villages and all their treasures' and the second guarantees them '... the full, exclusive and undisturbed possession of their lands and estates, forests and fisheries ... In its Muriwhenua report the Waitangi Tribunal found that Maori have never abandoned claims to their original fishing entitlements. ${ }^{30}$

\section{The Tribunal's Report and its Reception}

The Tribunal found that the Waitara river and the reefs constituted 'significant and traditional fishing grounds of specific hapu of Te Atiawa people'. 31 that these were being increasingly polluted, especially in the vicinity of the river mouth, and stood to be further polluted. Furthermore it found that construction of a new outfall at Motunui would be deleterious to the reefs thereabouts, there being no guarantee against further pollution. It found that the Crown had failed to recognise Maori interests which were guaranteed by the Treaty and which should have been protected by law.

In light of these findings, the Tribunal made three types of recommendations:

- Case specific

that the proposal for the Motunui outfall be stopped, that waste from the Synthetic Fuels plant should in the meantime be discharged through the Waitara Borough outfall;

- Regional

that a regional task force be established, to plan for the development of the region and associated infrastructure, and attend 'in the first instance' to replacement of the defective Waitara outfall and in the long term to provision of land-based disposal of waste;

- National

that a committee be established, with representatives from a number of government departments, to promote the recognition of Maori fishing grounds in law, and to protect them by improving the ways in which new developments are assessed. 32

The National Government's response to the Tribunal's report was 'awaited with interest as being probably the most important decision to draw formally on the Treaty for more than a century', said an editorial in the conservative South Island newspaper, The Press (30 March 1983). However the government, whose credibility by now hinged significantly on success of the Think Big projects, announced that the Motunui outfall would proceed immediately in order that the synthetic fuel plant could be finished on time. The Prime Minister dismissed the Tribunal's findings and sought once again to marginalise the environmental knowledge upon which it was based. He stated that 'there was no possibility of pollution from the outfall as all the necessary safety standards would be adhered to'; ${ }^{33}$ that all the evidence presented to the Tribunal had already been considered at the water rights

30 Waitangi Tribunal 1988: xiii.

31 Waitangi Tribunal 1983: 6.

32 Waitangi Tribunal 1983: 6.

33 The Press, 29 March 1983. 
hearings and that 'the technical appraisal of the scheme was a great deal more rigorous than any evidence discussed at the Waitangi enquiry'. ${ }^{34}$

In contrast the Tribunal had questioned the extent to which Pakeha scientific evidence should be preferred to the knowledge of Te Atiawa.

The Maori lore on the conservation and preservation of natural resources, as inherited by word of mouth, represents the collective wisdom of generations of people whose existence depended on their perception and observation of nature. We do not consider that the weight given to scientific evidence should be such as to denigrate the worth of customary law ... In the final analysis it is the test of experience (and the generations of the future) that will determine the worth of scientific postulates: ${ }^{35}$

Here was a clear recognition that scientific knowledge, far from being fixed and absolute, is also culturally defined.

As media and public pressure grew the Daily News, a local Taranaki paper, commented that it becomes clear that the government has grievously miscalculated the depth of opposition by Maori people and many Europeans to the discharge of industrial wastes into coastal waters which embrace traditional fishing grounds' ${ }^{36}$ On 9 th September 1983 , in a major political about turn, the Synthetic Fuels Plant (Effluent Disposal) Empowering Bill was passed, allowing Synfuels effluent to pass through the Waitara marine outfall. A North Taranaki Regional Wastewater Taskforce was then given responsibility for reporting on the provision of upgraded sewage facilities for Waitara. At the time a member of Te Atiawa commented that 'We now put our faith in the Taskforce to come to an early solution .... saving the Waitara river from suffering: ${ }^{37}$ In October 1986 after more than two years of study the Taskforce released its report and recommended the establishment of a new regional outfall at Waitara with land based treatment of all waste streams.

Following the report there were protracted negotiations between the Crown and the outfall users as to implementation of the recommendation. As delay grew so did Te Atiawa disgruntlement: "They [officialdom] have been doing it to us all along [delaying] ... A person can urinate in the street and be fined $\$ 100$ for it, but industry can spew tonnes of waste into the sea each day and still nothing is done'.38 In September 1988 Works Consultancy (a state-owned enterprise set up following the dissolution of the Ministry of Works and Development) provided an alternative proposal. This showed that the existing Waitara outfall could be upgraded to provide an acceptably low structural risk for a twenty five year life period. The New Plymouth District Council was given the responsibility for the renewal of the outfall and the construction of a treatment plant to treat the waste from Waitara township and the freezing works. These projects were both completed by February 1992, with 90 percent of the cost being met by the Crown.

In terms of the national recommendations made by the Waitangi Tribunal the Maori Fisheries Act passed in 1989 was designed to give protection to taipure, defined as fishing grounds controlled and managed by Maori. This in conjunction with the passing of the Resource Management Act in 1991 has established a regulatory framework which addresses the Tribunal's recommendations concerning Maori fishing resources.

\footnotetext{
34 The Press, 30 Marcb 1983.

36 Daily News, 4 April 1983.

37 Taranaki Catchment Commission 1983: 21.

38 Taranaki Herald, 21 January 1988.
} 


\section{THE MONIUNUI-WAITARA CLAIM TO THE WAITANGI TRIBUNAL}

\section{Conclusion}

This article has sought to show that there are two geographies of Taranaki (Figs 2 and 3), one imposed upon and obscuring the other. The first is overt, taken for granted by the majority Pakeha population, based on human authority over nature and reproduced through technocratic manipulation of resources. The other affords identity to Maori, even though much of its resources have been appropriated by the Crown and the knowledge upon which it is based and understood to operate was long excluded from mainstream forums.

The Motunui-Waitara claim occurred at a time and in a place that was conducive to the emergence of this other to wider view. However the chain of resistance to the Motunui outfall proposal demonstrated that those excluded by the dominant culture had by no means been silenced into a passive acceptance of their lot. The Tribunal itself contributed to the process of emergence of a different way of understanding 'place'. This was not only by providing the forum within which a previously marginalised geography could take centre stage, but also through making a politically attainable set of recommendations which gained widespread exposure through the media following their initial rejection by the government. ${ }^{39}$

It was suggested earlier that this was part of a process of reinterpretation and retrieval of New Zealand geographies. With the benefit of hindsight, the significance of the Motunui-Waitara findings was that they began the process, for Pakeha, of drawing attention to the appropriation and subsequent degradation of the traditional Maori resource base. They were a step along the way to revealing different histories, environmental knowledges and narratives of place. In response to this changing cultural climate, in 1985 the Fourth Labour Government extended the Tribunal's brief for the investigation of Treaty grievances back to 1840 . This action was part of a broader policy initiative to incorporate Maori aspirations in the political structure which also saw the Treaty included in significant pieces of resource management law, and which reallocated some resources to Maoridom via the purchase of fisheries quota by the state. ${ }^{40}$ The effectiveness of these policies in delivering substantial degrees of control over resources and of self determination has been questioned. ${ }^{41}$ However, since the Motunui-Waitara claim much that was once hidden from the gaze of the dominant culture is now coming into the open, albeit yet to be taken for granted. Aotearoa-New Zealand can be said to be not only retrieving and reinterpreting its geographies, but also in the process of inventing them anew.

\section{LIST OF REFERENCES}

Arnold, R. New Zealand's Burning. The Settlers' World in the mid 1880s, Victoria University Press, Wellington, 1994.

Belich, J. The New Zealand Wars and the Victorian Interpretation of Racial Conflict, Auckland University Press, Auckland, 1986.

Durie, E. The law and the land, in J. Phillips (ed), Te Whenua Te Iwi. The Land and the People. Allen and Unwin/Port Nicholson Press, Wellington, 78-81, 1987.

Henare, M. Nga tikanga me nga ritenga o te ao Maori. Standards and foundations of Maori society, in Report of the Royal Commission on Social Policy, Vol.3, Wellington, 3-41, 1988.

39 Waitangi Tribunal 1993.

40 Pawson 1992b.

41 Kelsey 1990. 


\section{ABORIGINAL HISTORY 1995 19:2}

James, P. Occurrence and Resolution of the Motunui-Waitara Resource Conflict (Wai-6). MSc thesis (Geography), University of Canterbury, 1993.

Kelsey, J. A Question of Honour? Labour and the Treaty 1984-1989. Allen and Unwin, Wellington, 1990.

Kirk, B. A history of the Motunui outfall, Report to the Taranaki Catchment Commission, New Plymouth, 1984.

Love, N. Submission to the Waitangi Tribunal (wai-143) in Taranaki Muru me te Raupatu Te Atiawa, 10-12 April 1991.

Maiden, C.J. New Zealand Gas to Gasoline Plant, New Zealand Synthetic Fuels Corporation, New Plymouth, 1983.

McDowell, L. The transformation of cultural geography, in Gregory, D., Martin R. and Smith, G. (eds), Human Geography. Society, Space and Social Science, University of Minnesota Press, Minneapolis: 146-173, 1994.

Oliver, W.H. Claims to the Waitangi Tribunal, Waitangi Tribunal Division, Department of Justice, Wellington, 1991

Pawson, E. Time-space convergence in New Zealand: 1850s-1990s, New Zealand Journal of Geography, 94, 14-19, 1992a.

, Two New Zealands: Maori and European in Anderson, K. and Gale, F. (eds), Inventing Places, Studies in Cultural Geography, Longman Cheshire, Melbourne, 15-33, 1992b.

Pawson, E. and Cant, G. Land rights in historical and contemporary context. Applied Geography, 12, 95-108, 1992.

Peet, J. New Zealand energy options: are we living in a fuels paradise? in Davis, P (ed), New Zealand Labour Perspectives 1. The Challenge of the Third Depression, Ross, Auckland, 2337, 1981.

Pitts, P. The Unquiet earth. Reading landscape and the land in New Zealand art, in Barr, M (ed), Headlands, Thinking Through New Zealand Art, The Museum of Contemporary Art, Sydney in collaboration with the National Art Gallery, New Zealand, 87-98, 1992.

Rawson, G.I. The evolution of the rural settlement pattern of rural south Taranaki 1860-1920, MA thesis (Geography), University of Canterbury, 1967.

Short, J.R. Imagined Country. Environment, Culture and Society, Routledge, London, 1991.

Sinclair, K. Kinds of Peace. Maori People after the Wars, 1870-85, Auckland University Press, Auckland, 1991.

Sorrensen, M.P.K. Towards a radical reinterpretation of New Zealand history: the role of the Waitangi tribunal, in I.H. Kawharu (ed), Waitangi. Maori and Pakeha Perspectives of the Treaty of Waitangi, Oxford University Press, Auckland, 158-178, 1989.

Stratford 50th Jubilee Publication. Carved from the Bush. Strafford 1878-1928, McLeod and Slade Ltd, New Plymouth, 1928.

Stokes, E. The Treaty of Waitangi and the Waitangi Tribunal: Maori claims in New Zealand. Applied Geography, 12, 176-91, 1992.

Taylor, A. Te Taha Maori. The Importance of the Sea and the Waterways to the Maori, and why Outfalls are unacceptable as Effluent Treatment. Nature Conservation Council Newsletter, no 60, March, 1986.

Taranaki Catchment Commission. Waitara Borough Council, wastewater report to the taranaki Catchment Commission and Regional Water Board, unpublished, 1983.

Walker, R. Ka Whawhai Tonu Matou. Struggle Without End, Penguin, Auckland, 1990.

Waitangi Tribunal. Finding of the Waitangi Tribunal on the Motunui/Waitara Claim (Wai-6), Wellington 1983.

Waitangi Tribunal. Report of the Waitangi Tribunal on the Muriwhenua Fishing Claim, Wellington 1988.

Waitangi Tribunal. Motunui-Waitara. The Waitangi Tribunal and the Motunui-Waitara claim, Wellington 1993. 


\section{THE MONIUNUI-WAITARA CLAIM TO THE WAITANGI TRIBUNAL}

\section{Postscript}

Since this article was accepted for publication, the Waitangi Tribunal has published a $\mathbf{3 7 0}$ page interim report on the 21 Taranaki land claims brought under the 1985 legislation. The report gives a full account of the loss of land by Te Atiawa and the other iwi and hapu of the region. The reference is The Taranaki Report: Kaupapa Tuatahi. Wai 143. Wellington, 1996. All Tribunal reports, including those on Taranaki and Motunui-Waitara, are now available on the Internet, at

http://www.knowledge-basket.co.nz/waitangi/welcome.html 